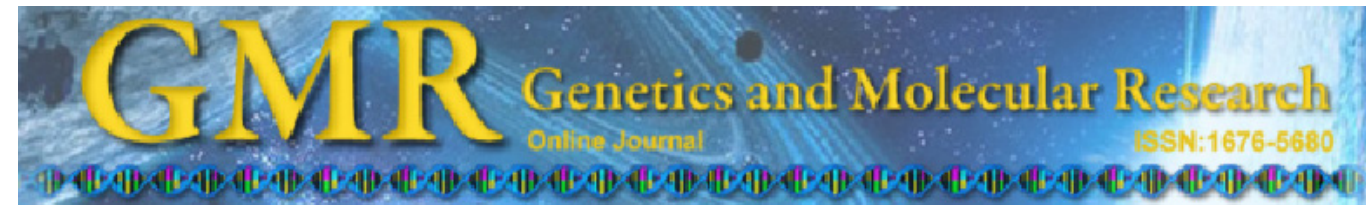

\title{
Polymorphisms associated with egg number at 300 days of age in chickens
}

\author{
H.P. Xu ${ }^{1 *}$, H. Zeng ${ }^{1 *}$, D.X. Zhang ${ }^{1}$, X.L. Jia ${ }^{1}$, C.L. Luo ${ }^{2}$, M.X. Fang ${ }^{3}$, \\ Q.H. Nie ${ }^{1}$ and X.Q. Zhang ${ }^{1}$ \\ ${ }^{1}$ Department of Animal Genetics, Breeding and Reproduction, \\ College of Animal Science, South China Agricultural University, \\ Guangzhou, Guangdong, China \\ ${ }^{2}$ Institute of Animal Science, \\ Guangdong Academy of Agricultural Sciences, \\ Guangzhou, Guangdong, China \\ ${ }^{3}$ Department of Laboratory Animal Science, \\ Medical College of Jinan University, Guangzhou, Guangdong, China \\ *These authors contributed equally to this study. \\ Corresponding author: X.Q. Zhang \\ E-mail: xqzhang@scau.edu.cn
}

Genet. Mol. Res. 10 (4): 2279-2289 (2011)

Received November 19, 2010

Accepted February 2, 2011

Published October 3, 2011

DOI http://dx.doi.org/10.4238/2011.October.3.5

\begin{abstract}
We looked for variations that could be associated with chicken egg number at 300 days of age (EN300) in seven genes of the hypothalamic-pituitary-gonadal axis, including gonadotrophin-releasing hormone-I $(G n R H-I)$, GnRH receptor $(G n R H R)$, neuropeptide $\mathrm{Y}(N P Y)$, dopamine D2 receptor $(D R D 2)$, vasoactive intestinal polypeptide $(V I P)$, VIP receptor-1 $(V I P R-1)$, prolactin $(P R L)$, and the QTL region between 87 and $105 \mathrm{cM}$ of the $Z$ chromosome. Ten mutations in the seven genes were chosen to do marker-trait association analyses in a population comprising 1310 chickens, which were obtained from a company located in Guangdong Province of China. The C1704887T of VIPR-1 was found to have a highly significant association with EN300. The T5841629C of DRD2 and the C1715301T of VIPR-1 were significantly associated with EN300. A highly significant association was also
\end{abstract}


found between the C1704887T-C1715301T haplotypes of VIPR-1 and EN300. H1H3 had the highest EN300. Four PCR-RFLP variations in the candidate QTL region were selected to investigate their genetic effects on EN300. The haplotypes of T32742468C-G32742603A in this region showed a highly significant association with EN300. Bioinformatics analyses showed that both T32742468C and G32742603A were located in intron 1 of the SH3-domain GRB2-like 2 (SH3GL2) gene. We conclude that five SNPs, including C1704887T and C1715301T of VIPR-1, T5841629C of DRD2, and T32742468C and G32742603A of SH3GL2, would be useful as markers for breeding to increase chicken EN300.

Key words: Association analysis; Chicken; Polymorphism; QTL; Candidate gene; Egg number at 300 days of age

\section{INTRODUCTION}

Egg production is an important economic trait in poultry. Endocrine factor (Kim et al., 2004) and many environment factors such as the length of photoperiod and different feeding allowances could influence egg production (Liu et al., 2004; Lewis and Gous, 2006). Nevertheless, the genetic factor is the prerequisite. Egg production is a polygenic inheritance trait with low to moderate heritability, which depends on the period involved (Emsley, 1997; Luo et al., 2007).

In poultry breeding programs, egg number at 300 days of age (EN300) is usually used as a valuable indicator for total egg production. The avian egg-production process is strictly controlled by the hypothalamic-pituitary-gonadal axis (Kuo et al., 2005). Gonadotropin-releasing hormone $(\mathrm{GnRH})$ is a key hormone located at the pinnacle of this axis (Shacham et al., 2001). GnRH, binding with its receptor GnRHR, stimulates gonadotrophin secretion from the pituitary gland and then evokes steroidogenesis in the gonads, resulting in egg production in hens (Shacham et al., 2001; Proudman et al., 2006; Sonez et al., 2010). Neuropeptide Y (NPY) is known to be involved in the regulation of reproductive function at the hypothalamic level through the control of GnRH secretion (Dhillon et al., 2009; Klenke et al., 2010). Beside this GnRH-gonadotrophin pathway, avian seasonal reproduction is also controlled by the vasoactive intestinal peptide (VIP) - prolactin (PRL) neuroendocrine pathway (Sharp, 2005; Leska and Dusza, 2007). Plasma PRL level had a negative effect on the chicken egg production (Reddy et al., 2007). VIP is a well-known hypothalamic PRL-releasing factor in avian (El Halawani et al., 1996) and its physiological effects are mediated through activating its specific receptor (Chaiseha et al., 2004). Furthermore, dopamine was demonstrated to play a dual role in PRL release by affecting VIP secretion, exerting its inhibitory effect via dopamine D2 receptor (DRD2) (A1 Kahtane et al., 2003). Therefore, GnRH-I, GnRHR, NPY, PRL, VIP and one of its receptors, $V I P R-1$, as well as DRD2 were regarded as candidates of chicken EN300 in this study.

Many studies have been performed to identify QTL regulating chicken egg number (Hansen et al., 2005; Schreiweis et al., 2006; Chatterjee et al., 2010). QTL influencing the egg number from 16 to 25 weeks of age was mapped to chromosome 4, whereas QTL related 
to the egg number between 18 and 40 weeks of age were mapped to chromosome $8, \mathrm{Z}$ and 11 (Tuiskula-Haavisto et al., 2002, 2004; Schreiweis et al., 2006). Additionally, the QTL region between 87 and $105 \mathrm{cM}$ of the $\mathrm{Z}$ chromosome was found to affect the egg number from 18 to 40 weeks of age and from 41 to 60 weeks of age, the average egg weight of these two periods, as well as the age of first egg (AFE) (Tuiskula-Haavisto et al., 2002; Sasaki et al., 2004). In the present study, this area was taken as the candidate QTL region for EN300.

Although there have been increasing studies on the relationship of genes with egg production (Dunn et al., 2004; Xu et al., 2010a), few genetic markers applied in MAS have been obtained. The objective of this study was to identify variations associated with EN300 in the candidate genes and QTL region. In this study, SNPs in the candidate QTL region were identified by direct sequencing. Subsequently, 10 mutations in the candidate genes and 4 PCR-RFLP variations in the QTL region were chosen to test their association with EN300 in a Chinese native chicken population.

\section{MATERIAL AND METHODS}

\section{Chicken populations}

A population comprising 1310 Ningdu Sanhuang (NDH) female individuals from one hatch were used for association analyses in the present study. All chickens were obtained from a female line of the Guangdong Wens Foodstuff Company Ltd., Guangdong, China. NDH was a Chinese native chicken breed originating from the Jiangxi Province, China, and its total egg production for 500 days of age was about 113 eggs. Chickens had been kept in closed breeding for five generations, and the fifth generation population was used in the present study. All birds were fed ad libitum to 77 days of age with a diet of $2837 \mathrm{kcal} \mathrm{ME} / \mathrm{kg}$ and then changed to restrict feed with a diet of $2907 \mathrm{kcal} \mathrm{ME} / \mathrm{kg}$. During the first 2 days post-hatch, all individuals were exposed to a continuous 24-h photoperiod and then transferred to a $16-\mathrm{h}$ photoperiod. All females were housed in individual laying cages after 91 days of age and their egg production was observed and recorded at 16:00 h every day. Finally, the number of eggs produced from 91 to 300 days of age was calculated individually. The average value of EN300 in this population was 94.0 eggs. Blood samples were collected from the vein under the wing after 300 days of age and genomic DNA was extracted.

In addition, 10 randomly selected NDH chickens were used for polymorphism identification in the candidate QTL region (32.17 34.26 Mb of the $\mathrm{Z}$ chromosome).

\section{SNP identification and selection}

Based on the dbSNP database (http://www.ncbi.nlm.nih.gov/entrez/query. fcgi? $\mathrm{CMD}=$ search $\& \mathrm{DB}=\mathrm{snp}$ ) and previous reports (Cui et al., 2006; Zhou et al., 2008b, 2010; $\mathrm{Xu}$ et al., 2010b), 10 variations in 7 candidate genes, including GnRH-I, GnRHR, $N P Y, D R D 2, V I P, V I P R-I$, and $P R L$, were used to analyze their effects on EN300. A total of 10 pairs of primers were designed by the Genetool software (http://www.biologysoft.com/; BioTools, Alberta, Canada) to genotype the above variations (Table 1). 
Table 1. Detail information for primers of the candidate genes of EN300.

\begin{tabular}{|c|c|c|c|c|c|c|c|}
\hline No. & Site & Chr & Gene & Primer sequence $\left(5^{\prime} \rightarrow 3^{\prime}\right)$ & Length (bp) & AT $\left({ }^{\circ} \mathrm{C}\right)$ & Restriction enzyme \\
\hline M1 & G840327C & $\mathrm{Chr} 22$ & GnRH-I & $\begin{array}{l}\text { F:tgtcacacccaggatctcaa } \\
\text { R:gctgttcagaggcacgtgag }\end{array}$ & 310 & 59.0 & MnII \\
\hline M2 & A19960831G & Chr10 & GnRHR & $\begin{array}{l}\text { F:ggtgtctgaggctcattca } \\
\text { R:tagcaatcgettgeccaga }\end{array}$ & 417 & 58.0 & Bpu1102I \\
\hline M3 & I31391359D & $\mathrm{Chr} 2$ & $N P Y$ & $\begin{array}{l}\text { F:tctcagagctccaacgtatga } \\
\text { R:atatttctgtgcctgaacaaca }\end{array}$ & $248 / 252$ & 58.0 & DraI \\
\hline M4 & C31394761T & $\mathrm{Chr} 2$ & $N P Y$ & $\begin{array}{l}\text { F:cgtggctgctttgcttcctttc } \\
\text { R:ggggtacgaggcaaggacatg }\end{array}$ & 324 & 60.0 & $K p n \mathrm{I}$ \\
\hline M5 & T5841629C & Chr24 & $D R D 2$ & $\begin{array}{l}\text { F:tgcacataaaagcccactcactg } \\
\text { R:gcctgagctggtgggggg }\end{array}$ & 248 & 60.0 & BseGI \\
\hline M6 & G51389822T & Chr3 & $V I P$ & $\begin{array}{l}\text { F:gcttggactgatgcgtactt } \\
\text { R:gtatcactgcaaatgctctgc }\end{array}$ & 520 & 58.0 & ApoI \\
\hline M7 & A1661691G & $\mathrm{Chr} 2$ & $V I P R-1$ & $\begin{array}{l}\text { F:tgaaagcccccaggatct } \\
\text { R:agcaaacaaaacccaaatca }\end{array}$ & 364 & 58.2 & TaiI \\
\hline M8 & C1704887T & $\mathrm{Chr} 2$ & VIPR-1 & $\begin{array}{l}\text { F:ccccgttaaactcagcagac } \\
\text { R:cccaaagtcccacaaggtaa }\end{array}$ & 434 & 58.2 & HhaI \\
\hline M9 & $\mathrm{C} 1715301 \mathrm{~T}$ & $\mathrm{Chr} 2$ & $V I P R-1$ & $\begin{array}{l}\text { F:ctcctcaggcagaccatcatg } \\
\text { R:cttgcacgtatccttgggtagc }\end{array}$ & 486 & 58.2 & TaqI \\
\hline M10 & I59724210D & $\mathrm{Chr} 2$ & $P R L$ & $\begin{array}{l}\text { F:tttaatattggtgggtgaagagaca } \\
\text { R:atgccactgatcctcgaaaactc }\end{array}$ & $130 / 154$ & 54.0 & PCR \\
\hline
\end{tabular}

The sites are based on the chicken genome sequences released in May 2006 (http://genome.ucsc.edu/cgi-bin/ hgGateway). Chr refers to chromosome. Length indicates the length of PCR products. AT refers to annealing temperature.

Based on the genomic sequence of the $87 \sim 105 \mathrm{cM}$ (about $32.17 \sim 34.26 \mathrm{Mb}$ ) region on the $\mathrm{Z}$ chromosome (http://www.ensembl.org/Gallus_gallus/Index.html), 5 pairs of primers (P1 to P5) were designed to scan polymorphisms of the QTL region, and the average distance between 2 adjacent pairs of primers was $500 \mathrm{~kb}$ (Table 2). PCR products were then subcloned into the pMD18-T vector (TaKaRa Biotechnology Co., Ltd., Dalian, China) and sequenced by a commercial company (Biosune, Shanghai, China). The sequences were analyzed by the DNASTAR software (http://www.dnastar.com/).

Among the identified variations, only 4 markers could be easily genotyped by PCRRFLP. Therefore, 3 pairs of primers (M11, M13 and M14 in Table 2) were designed and synthesized for genotyping these 4 markers in association analyses.

\section{PCR amplification and genotyping of polymorphisms}

PCR amplification was carried out in a final volume of $25 \mu \mathrm{L}: 50 \mathrm{ng}$ genomic DNA, $1 \mu \mathrm{M}$ of each primer, $200 \mu \mathrm{M}$ dNTP, $1.5 \mathrm{mM} \mathrm{MgCl}$, 1 X PCR buffer, and 1.0 U Taq DNA polymerase (Sangon Biological Engineering Technology Company, Shanghai, China), using an Eppendorf Mastercycler (Eppendorf Limited, Hamburg, Germany). The following reaction conditions were used: initial denaturation at $94^{\circ} \mathrm{C}$ for $4 \mathrm{~min} ; 35$ cycles of $94^{\circ} \mathrm{C}$ for $30 \mathrm{~s}$, $\mathrm{n}^{\circ} \mathrm{C}$ ( $\mathrm{n}$ was the annealing temperature shown in Tables 1 and 2) for $35 \mathrm{~s}, 72^{\circ} \mathrm{C}$ for $35 \mathrm{~s}$, and a final elongation at $72^{\circ} \mathrm{C}$ for $7 \mathrm{~min}$. Genotyping assay of M10 was directly observed by $3.5 \%$ agarose gel electrophoresis after PCR amplification. Genotypes of the other polymorphisms were determined by the PCR-RFLP method. According to the manufacturer protocol, $8 \mu \mathrm{L}$ PCR products was further digested at $37^{\circ} \mathrm{C}\left(55^{\circ} \mathrm{C}\right.$ for $B s e \mathrm{GI}, 65^{\circ} \mathrm{C}$ for $\mathrm{Tai}$ and $\mathrm{Taq}$ I) overnight. After digestion, the products were subjected to $2.5 \%$ agarose gel electrophoresis, and the genotypes were determined with a TFM-40 Ultraviolet Transilluminator (UVP Company, Cambridge, UK) by ethidium bromide staining. 


\begin{tabular}{|c|c|c|c|c|c|}
\hline Primer & Primers sequences $\left(5^{\prime} \rightarrow 3^{\prime}\right)$ & Location (nt)/site & Length (bp) & AT $\left({ }^{\circ} \mathrm{C}\right)$ & Restriction enzyme \\
\hline P1 & $\begin{array}{l}\text { F:acagctaaagcagacaagtgac } \\
\text { R:cagggaaaaagagagcattatc }\end{array}$ & 32173030 to 32173816 & 787 & 58 & / \\
\hline P2 & $\begin{array}{l}\text { F:aggagctgggtgacattgtg } \\
\text { R:tggggtaaggacagcacagt }\end{array}$ & 32742159 to 32742879 & 721 & 58 & l \\
\hline P3 & $\begin{array}{l}\text { F:gagggaaatgggaagcaaagtag } \\
\text { R:gccaaaagctgaaagtaggtctg }\end{array}$ & 33379518 to 33380294 & 777 & 62 & I \\
\hline P4 & $\begin{array}{l}\text { F:ttgcctactcacctggatgt } \\
\text { R:ggagggaagtgggaaggatt }\end{array}$ & 33824372 to 33825087 & 716 & 58 & / \\
\hline P5 & $\begin{array}{l}\text { F:accgettcctgtgttcttaatc } \\
\text { R:tgcaaggatgtcaaaaattatg }\end{array}$ & 34263732 to 34264499 & 768 & 60 & l \\
\hline M11 & $\begin{array}{l}\text { F:aggagctgggtgacattgtg } \\
\text { R:tggggtaaggacagcacagt }\end{array}$ & T32742394C & 721 & 58 & MspI \\
\hline M12 & $\begin{array}{l}\text { F:aggagctgggtgacattgtg } \\
\text { R:tggggtaaggacagcacagt }\end{array}$ & T32742468C & 721 & 58 & $P a u \mathrm{I}$ \\
\hline M13 & $\begin{array}{l}\text { F:tgcaagcccaggaatcatcactc } \\
\text { R:taaaactcttctttccttctaca }\end{array}$ & G32742603A & 294 & 58 & $A l u \mathrm{I}$ \\
\hline M14 & $\begin{array}{l}\text { F:tcttcgaacacattactcactga } \\
\text { R:ggcgttttgtgtttcttggcat }\end{array}$ & C33379782T & 400 & 57 & AluI \\
\hline
\end{tabular}

Location is based on chicken $\mathrm{Z}$ chromosome. Length indicates PCR product length. AT refers to annealing temperature.

\section{Statistical analyses of haplotypes}

The haplotype structure was analyzed by the Haploview version 3.32 software (http://www.broad.mit.edu/mpg/haploview/). Haplotypes were constructed based on the genotype data by the PHASE 2.0 software (http://en.wikipedia.org/wiki/Phase).

\section{Marker-trait association analyses}

Association analyses of polymorphisms or haplotypes with the chicken EN300 were carried out by the SAS GLM procedure (SAS Institute Inc., Cary, NC, USA), and the genetic effects were evaluated by the mixed model as follows:

$$
Y=\mu+G+F+e,
$$

where $Y$ is a trait observation, $\mu$ is the overall population mean, $G$ is the fixed effect of genotype or haplotype, $F$ is the random effect of family, and $e$ is the residual error. Multiple comparisons were conducted with least square means. A $\mathrm{P} \leq 0.05$ was considered to be significant in all analyses.

\section{Bioinformatics analyses in the QTL region}

Gene mapping and function analyses of variations associated with EN300 in the candidate QTL region were performed on bioinformatic websites of www.ncbi.nih.gov/ mapview/ and www.ensembl.org/Gallus_gallus/index.html. 


\section{RESULTS}

\section{Genotype and haplotype of the 7 candidate genes}

Three genotypes were found in each of M1-M10 in the candidate genes of EN300. For the $N P Y$ gene, 4 distinct haplotypes, E1, E2, E3, and E4, with each frequency higher than $1 \%$, were present in the haplotype block composed of I31391359D and C31394761T (Block 1). Among the four haplotypes, E1 (47.51\%) and E4 (25.71\%) were the predominant ones, whereas E2 $(17.19 \%)$ and E3 $(9.59 \%)$ were minor. On the other hand, haplotype structure analyses showed that there was a haplotype block for the 3 SNPs of the VIPR-1 gene, and it was composed of M8 and M9 (Block 2). Four haplotypes were observed, and 3 of these, namely H1 (CT, 18.91\%), H2 (CC, 77.69\%) and H3 (TC, 3.04\%), had a frequency higher than 1\%.

\section{Association of variations in the 7 candidate genes with EN300}

As shown in Table 3, a highly significant association was found between the $\mathrm{C} 1704887 \mathrm{~T}$ of the chicken VIPR-1 gene and the EN300 $(\mathrm{P}<0.01)$, and chickens with the TT genotype had a lower EN300 than those with the TC and CC genotypes $(\mathrm{P}<0.01$, highly significant). Furthermore, the C1715301T of the VIPR-1 gene was significantly associated with EN300 $(\mathrm{P}<0.05)$, and allele $\mathrm{T}$ was advantageous for chicken EN300 (Table 4). The T5841629C of the DRD2 gene also showed a significant association with EN300 ( $\mathrm{P}<0.05)$. In addition, the EN300 values of individuals with the TT genotype were higher than those with the CC and TC genotypes ( $\mathrm{P}<0.01$, highly significant). No significant association was found in the other variation sites (G840327C of GnRH-I, A19960831G of GnRHR, I31391359D and C31394761T of NPY, G51389822T of VIP, A1661691G of VIPR-1, and I59724210D of $P R L)$ with EN300 (P $>0.05)$.

\section{Association of the haplotypes in the 7 candidate genes with chicken EN300}

A total of $1204 \mathrm{NDH}$ individuals with 9 diplotypes (246 of E1E1, 216 of E1E2, 131 of E1E3, 305 of E1E4, 41 of E2E2, 116 of E2E4, 12 of E3E3, 76 of E3E4, and 61 of E4E4) were used in association analyses in the haplotype block composed of I31391359D-C31394761T in the $N P Y$ gene. No significant association was found in this haplotype block with chicken EN300 $(\mathrm{P}>0.05)$.

A total of $1295 \mathrm{NDH}$ individuals with 6 diplotypes, including 114 of H1H1, 249 of $\mathrm{H} 1 \mathrm{H} 2,14$ of $\mathrm{H} 1 \mathrm{H} 3,853$ of $\mathrm{H} 2 \mathrm{H} 2,60$ of $\mathrm{H} 2 \mathrm{H} 3$, and 5 of $\mathrm{H} 3 \mathrm{H} 3$, were used in association analyses in the haplotype composed of C1704887T-C1715301T in the VIPR-1 gene. A highly significant association $(\mathrm{P}<0.01)$ was found between the haplotypes and chicken EN300 (Table 4). $\mathrm{H} 3 \mathrm{H} 3$ had a lower value of EN300 than other diplotypes ( $\mathrm{P}<0.01$, highly significant). Nevertheless, $\mathrm{H} 1 \mathrm{H} 3$ had much higher EN300 values and was significantly different from $\mathrm{H} 1 \mathrm{H} 2$ and $\mathrm{H} 2 \mathrm{H} 2(\mathrm{P}<0.05)$. H2H2 was also shown to be significantly different from $\mathrm{H} 1 \mathrm{H} 1(\mathrm{P}<0.05)$.

\section{Polymorphisms in the QTL region and their association with EN300}

Sixteen variations were found in a total of $3769 \mathrm{bp}$ in the 32.17 to $34.26 \mathrm{Mb}$ region of the chicken $\mathrm{Z}$ chromosome (shown in Table 5). Four PCR-RFLP markers, including 
T32742394C, T32742468C, G32742603A, and C33379782T, were selected to perform marker-trait association analyses. The results are shown in Table 6, and no significant association was detected between any of the 4 sites and EN300 (P $>0.05)$.

Table 3. Association of variations in the candidate genes with chicken EN300.

\begin{tabular}{|c|c|c|c|c|c|c|c|}
\hline No. & Candidate gene & $\mathrm{Chr}$ & Site & Genotype & $\mathrm{N}$ & EN300 & $\mathrm{P}$ value \\
\hline \multirow[t]{3}{*}{ M1 } & \multirow[t]{3}{*}{ GnRH-I } & \multirow[t]{3}{*}{ Chr22 } & \multirow[t]{3}{*}{ G840327C } & $\mathrm{CC}$ & 26 & $93.31 \pm 5.46$ & \multirow[t]{3}{*}{0.592} \\
\hline & & & & $\mathrm{GC}$ & 208 & $96.28 \pm 1.97$ & \\
\hline & & & & GG & 972 & $94.12 \pm 0.86$ & \\
\hline \multirow[t]{3}{*}{ M2 } & \multirow[t]{3}{*}{ GnRHR } & \multirow[t]{3}{*}{ Chr10 } & \multirow[t]{3}{*}{ A19960831G } & GG & 30 & $96.40 \pm 4.91$ & \multirow[t]{3}{*}{0.531} \\
\hline & & & & GA & 420 & $92.99 \pm 1.29$ & \\
\hline & & & & AA & 823 & $94.60 \pm 0.95$ & \\
\hline \multirow[t]{3}{*}{ M3 } & \multirow[t]{3}{*}{$N P Y$} & \multirow[t]{3}{*}{ Chr2 } & \multirow[t]{3}{*}{ I31391359D } & II & 156 & $93.18 \pm 2.11$ & \multirow[t]{3}{*}{0.622} \\
\hline & & & & ID & 578 & $93.59 \pm 1.10$ & \\
\hline & & & & DD & 522 & $95.00 \pm 1.18$ & \\
\hline \multirow[t]{3}{*}{ M4 } & \multirow[t]{3}{*}{$N P Y$} & \multirow[t]{3}{*}{ Chr2 } & \multirow[t]{3}{*}{ C31394761T } & $\mathrm{CC}$ & 392 & $94.55 \pm 1.35$ & \multirow[t]{3}{*}{0.923} \\
\hline & & & & $\mathrm{TC}$ & 600 & $94.20 \pm 1.08$ & \\
\hline & & & & $\mathrm{TT}$ & 214 & $95.04 \pm 1.85$ & \\
\hline \multirow[t]{3}{*}{ M5 } & \multirow[t]{3}{*}{$D R D 2$} & \multirow[t]{3}{*}{ Chr24 } & \multirow[t]{3}{*}{ T5841629C } & $\mathrm{CC}$ & 1060 & $94.03 \pm 0.83^{\mathrm{A}}$ & \multirow[t]{3}{*}{$0.025^{*}$} \\
\hline & & & & $\mathrm{TC}$ & 217 & $92.83 \pm 1.94^{\mathrm{A}}$ & \\
\hline & & & & TT & 5 & $124.64 \pm 11.66^{\mathrm{B}}$ & \\
\hline \multirow[t]{3}{*}{ M6 } & \multirow[t]{3}{*}{$V I P$} & \multirow[t]{3}{*}{ Chr3 } & \multirow[t]{3}{*}{ G51389822T } & GG & 74 & $95.52 \pm 3.16$ & \multirow[t]{3}{*}{0.179} \\
\hline & & & & GT & 400 & $96.50 \pm 1.37$ & \\
\hline & & & & TT & 732 & $93.26 \pm 1.01$ & \\
\hline M7 & VIPR-1 & $\mathrm{Chr} 2$ & A1661691G & GG & 1028 & $94.27 \pm 0.87$ & 0.204 \\
\hline & & & & GA & 95 & $98.81 \pm 2.91$ & \\
\hline & & & & AA & 83 & $92.12 \pm 3.93$ & \\
\hline M8 & $V I P R-1$ & Chr2 & $\mathrm{C} 1704887 \mathrm{~T}$ & $\mathrm{CC}$ & 1128 & $94.38 \pm 0.79^{\mathrm{A}}$ & $0.007 * *$ \\
\hline & & & & $\mathrm{TC}$ & 72 & $98.70 \pm 3.19^{\mathrm{A}}$ & \\
\hline & & & & TT & 6 & $65.08 \pm 10.70^{\mathrm{B}}$ & \\
\hline M9 & VIPR-1 & Chr2 & $\mathrm{C} 1715301 \mathrm{~T}$ & $\mathrm{CC}$ & 842 & $93.57 \pm 0.91^{\mathrm{a}}$ & $0.050^{*}$ \\
\hline & & & & $\mathrm{TC}$ & 252 & $95.32 \pm 1.68^{\mathrm{ab}}$ & \\
\hline & & & & $\mathrm{TT}$ & 112 & $100.10 \pm 2.55^{\mathrm{b}}$ & \\
\hline M10 & $P R L$ & Chr2 & I59724210D & II & 10 & $85.01 \pm 8.34$ & 0.154 \\
\hline & & & & ID & 187 & $97.29 \pm 1.95$ & \\
\hline & & & & DD & 1009 & $93.99 \pm 0.85$ & \\
\hline
\end{tabular}

Chr indicates chromosome. Site refers to the corresponding chromosomal location of chicken genome sequences (http://genome.ucsc.edu/cgi-bin/hgGateway; released in May 2006). N indicates the number of chickens tested for each genotype. EN300 = total egg number at 300 days of age; the values are shown with least-square means \pm standard errors (SE). ${ }^{\mathrm{a}, \mathrm{b}}$ or ${ }^{\mathrm{A}, \mathrm{B}}$ values with no common superscripts within a column for each site differ significantly $(* \mathrm{P}<0.05)$ or highly significantly $(* * \mathrm{P}<0.01)$.

\section{Table 4. Association of the haplotype blocks with EN300.}

\begin{tabular}{|c|c|c|c|c|c|}
\hline Block 1 & EN300 & Block 2 & EN300 & Block 3 & EN300 \\
\hline E1E1 (246) & $95.29 \pm 1.71$ & H1H1 (114) & $99.33 \pm 2.56^{\mathrm{c}}$ & I1I1 (429) & $94.60 \pm 1.38^{\mathrm{A}}$ \\
\hline E1E2 (216) & $96.06 \pm 1.82$ & H1H2 (249) & $93.86 \pm 1.71^{\mathrm{bc}}$ & $\mathrm{I} 1 \mathrm{I} 3(5)$ & $22.75 \pm 11.65^{\mathrm{B}}$ \\
\hline E1E3 (131) & $94.53 \pm 2.31$ & H1H3 (14) & $109.49 \pm 7.26^{\mathrm{ac}}$ & I2I2 (29) & $101.81 \pm 5.06^{\mathrm{A}}$ \\
\hline E1E4(305) & $93.03 \pm 1.53$ & $\mathrm{H} 2 \mathrm{H} 2(853)$ & $93.28 \pm 0.93^{\mathrm{b}}$ & I3I3 (399) & $92.27 \pm 1.48^{\mathrm{A}}$ \\
\hline E2E2 (41) & $92.55 \pm 4.06$ & H2H3 (60) & $96.23 \pm 3.55^{\mathrm{abc}}$ & I3I4 (62) & $95.15 \pm 3.54^{\mathrm{A}}$ \\
\hline E2E4 (116) & $95.18 \pm 2.47$ & H3H3 (5) & $60.49 \pm 11.92^{\mathrm{B}}$ & I4I4 (372) & $95.02 \pm 1.50^{\mathrm{A}}$ \\
\hline E3E3 (12) & $86.67 \pm 7.43$ & & & & \\
\hline E3E4 (76) & $92.80 \pm 3.05$ & & & & \\
\hline E4E4 (61) & $97.17 \pm 3.35$ & & & & \\
\hline$P$ value & 0.827 & & $0.003 * *$ & & $0.0001 * *$ \\
\hline
\end{tabular}

Blocks 1, 2 and 3 refer to the haplotype of I31391359D-C31394761T of NPY, the haplotype of C1704887TC1715301T of VIPR-1 and the haplotype of T32742468C-G32742603A in the QTL region, respectively. Data are reported as least-square means \pm standard errors (SE); numbers in parentheses indicate the number of chickens tested for each diplotype. EN300 = total egg number at 300 days of age. ${ }^{\text {ab, }, c}$ Means within a column with no common superscripts differ significantly $(\mathrm{P}<0.05$ or $\mathrm{P}<0.01)$. **Indicates $\mathrm{P}<0.01$. 


\begin{tabular}{|c|c|c|c|c|c|}
\hline No. & SNP & Restriction enzyme & No. & SNP & Restriction enzyme \\
\hline 1 & A32173202C & / & 9 & T32742468C & $\operatorname{PauI} / B \operatorname{sh} 1236 \mathrm{I}$ \\
\hline 2 & T32173392A & / & 10 & A32742557G & I \\
\hline 3 & A32173403T & $A l u \mathrm{I}$ & 11 & G32742603A & BauI/AluI \\
\hline 4 & $\mathrm{C} 32173455 \mathrm{~T}$ & / & 12 & T32742747G & / \\
\hline 5 & T32173517C & / & 13 & $\mathrm{C} 32742849 \mathrm{~T}$ & / \\
\hline 6 & G32742256A & / & 14 & $\mathrm{C} 33379782 \mathrm{~T}$ & $A l u \mathrm{I}$ \\
\hline 7 & C32742374G & / & 15 & G33380110A & / \\
\hline 8 & T32742394C & MspI & 16 & G34263878A & Ssil \\
\hline
\end{tabular}

SNP location is the location on the $\mathrm{Z}$ chromosome referred to the released chicken genomic sequence (http:// genome.ucsc.edu/; released in May 2006).

Table 6. Association of the 4 SNPs with chicken EN300.
\begin{tabular}{llcccc}
\hline No. & Location & Genotype & N & EN300 & P value \\
\hline M11 & T32742394C & C & 415 & $92.90 \pm 1.44$ & 0.4080 \\
& & T & 797 & $94.43 \pm 0.98$ & 0.6563 \\
M12 & T32742468C & C & 443 & $94.40 \pm 1.33$ & 0.1022 \\
& & T & 769 & $93.63 \pm 0.99$ & 0.1793 \\
M13 & G32742603A & G & 400 & $95.91 \pm 1.43$ & $92.91 \pm 0.97$ \\
M14 & C33379782T & C & 812 & $97.45 \pm 2.74$ & \\
& & T & 102 & $93.60 \pm 0.79$ & \\
\hline
\end{tabular}

The sites refer to the location on the $\mathrm{Z}$ chromosome of the chicken genome sequences (http://genome.ucsc.edu/cgibin/hgGateway; released in May 2006). N indicates the number of chickens tested for each genotype. EN300 = total egg number at 300 days of age; the values are reported as least-square means \pm standard errors (SE).

\section{Haplotype structure of the 4 sites in the QTL region and their association with EN300}

For the 4 variations of the $\mathrm{Z}$ chromosome, a haplotype block composed of T32742468C and G32742603A was detected in the NDH population (Block 3). In this block, 4 haplotypes, including I1 (CG, 33.24\%), I2 (CA, 2.31\%), I3 (TG, 33.36\%), and I4 (TA, 31.08\%), were observed. A total of 1296 chickens with 6 diplotypes (429 of I1I1, 5 of I1I3, 29 of I2I2, 399 of I3I3, 62 of I3I4, and 372 of I4I4) were used for the following association analyses, and the results are shown in Table 4. The haplotype of T32742468C and G32742603A showed a highly significant association $(\mathrm{P}<0.01)$ with chicken EN300. Compared to other diplotypes, I1I3 had lower value of EN300, which was highly significant $(\mathrm{P}<0.01)$.

\section{Bioinformatics analyses}

Bioinformatics analyses of the QTL region were conducted on the basis of Ensembl database (http://www.ensembl.org/Gallus_gallus/index.html). Both T32742468C and G32742603A, which constructed the haplotype block related to EN300, were located in intron 1 of the chicken SH3-domain GRB2-like 2 (SH3GL2) gene.

\section{DISCUSSION}

As a valuable index for overall egg production, EN300 has been widely studied, and 
the identification of molecular markers for it has been well performed (Dunn et al., 2004; Xu et al., 2010a; Zhou et al., 2010). In a commercial broiler breeder hen population, Dunn et al. (2004) detected polymorphisms of the GnRHR and NPY genes and discovered an SNP in the intron 1 of the GnRHR gene and a 4-bp indel located 700 bp upstream of the NPY transcription start site. Subsequently, marker-trait association analyses were carried out, but no association of these two variations with total egg production was found. Similarly, in this study, the same sites including the site I31391359D of the NPY gene and the A19960831G of the GnRHR gene were selected to analyze their effects on EN300, and the results were compatible with findings of Dunn et al. (2004). Previous reports confirmed that active immunization with VIP could increase egg production in turkeys (El Halawani et al., 1995; Caldwell et al., 1999). Also, another study discovered that an AGG indel in the 5' regulatory region of the VIP gene was related to EN300 (Zhou et al., 2010). However, another polymorphism in the intron 2 of the VIP gene, G51389822T, was not significantly associated with EN300, which was in agreement with the report by Zhou et al. (2010). On the other hand, it has been demonstrated that the PRL expression is correlated with the egg number (Shiue et al., 2006; Chen et al., 2007). In an $\mathrm{F}_{2}$ population produced from Nongdahe $\times$ Taihe Silkies chicken, Cui et al. (2006) proved that a 24-bp indel at the site of -358 of the $P R L$ gene was associated with egg production. However, the results of this study did not find any association between this 24-bp indel and EN300.

The dopaminergic system has been shown to play an important role in the regulation of the avian reproductive system and these physiological effects are exerted by activating its receptors (Sartsoongnoen et al., 2008; Xu et al., 2010b). Although Xu et al. (2010a) did not find any association between the polymorphisms in the coding region of DRD1 and EN300, variation of the DRD2 gene exhibited a significant association with chicken EN300 in this study. As indicated by the present study, C1704887T, which is located in intron 6 of the VIPR1 gene, was demonstrated to have a highly significant effect on chicken EN300. The haplotype analysis based on C1704887T and C1715301T of the VIPR-1 gene also validated this result. It was interesting that these findings about the VIPR-1 gene were in accordance with the previous investigation, which was performed in a different population (Zhou et al., 2008b). On the other hand, other studies proved that the C1715301T of the VIPR-1 gene has significant effects on both duration of broodiness and AFE, in which chickens with the CC genotype have longer duration of broodiness and earlier AFE than those with the TT genotype (Zhou et al., 2008a,b). In this study, we found that individuals with the CC genotype of C1715301T have lower EN300 than those with the TT genotype. These results suggest that EN300 in this site might be negatively affected by chicken broodiness. Thus, C1704887T and C1715301T in the $V I P R-1$ gene, as well as T5841629C of the DRD2 gene, may serve as important molecular markers of high egg production.

A QTL region close to the centromere of the $\mathrm{Z}$ chromosome was found to have effects on sexual maturity, egg weight, and number of eggs in both 18-40 weeks of age and 40-60 weeks of age (Tuiskula-Haavisto et al., 2002). In the present study, the haplotype of T32742468C - G32742603A in this region was also shown to be related to chicken EN300, even though no association was found between any of these single sites and the trait. These results confirmed previous findings that the association analysis of haplotype with traits was more predominant and reliable (Zhang et al., 2002; Rodriguez et al., 2006). Meanwhile, through bioinformatics analysis, we found that these two SNPs were located in the intron region of the SH3GL2 gene. SH3GL2, also known as endophilin I, SH3P4, CNSA2, 
and SH3D2A, is a member of the endophilin family and it contains 353 amino acids. Previous studies in mammals proved that SH3GL2 was essential for synaptic vesicle endocytosis (Schmidt et al., 1999; Reutens and Begley, 2002). Moreover, Hirayama et al. (2003) found that the endophilin family members differentially contributed to chicken oocyte endocytosis and development. Therefore, it seemed that the SH3GL2 gene may be one of the causative genes responsible for chicken egg production and that T32742394C and G32742603A may play a crucial role in EN300. However, the confirmation of their genetic effects on EN300 still requires further study.

In conclusion, a total of 5 polymorphisms of the DRD2, VIPR-1, and SH3GL2 genes were demonstrated to be associated with EN300. The information derived from this study is useful to enhance the breeding process with regard to chicken egg production.

\section{ACKNOWLEDGMENTS}

Research supported by the Major State Basic Research Development Program of China (\#2006CB102107) and China National Broiler Industrialized Technology Program (\#nycytx42-G1-04), as well as the China Postdoctoral Science Foundation (project \#20100470933).

\section{REFERENCES}

Al Kahtane, Chaiseha Y and El Halawani M (2003). Dopaminergic regulation of avian prolactin gene transcription. J. Mol. Endocrinol. 31: 185-196.

Caldwell SR, Johnson AF, Yule TD, Grimes JL, et al. (1999). Increased egg production in juvenile turkey hens after active immunization with vasoactive intestinal peptide. Poult. Sci. 78: 899-901.

Chaiseha Y, Youngren OM and El Halawani ME (2004). Expression of vasoactive intestinal peptide receptor messenger RNA in the hypothalamus and pituitary throughout the turkey reproductive cycle. Biol. Reprod. 70: 593-599.

Chatterjee R, Sharma RP, Bhattacharya TK, Niranjan M, et al. (2010). Microsatellite variability and its relationship with growth, egg production, and immunocompetence traits in chickens. Biochem. Genet. 48: 71-82.

Chen CF, Shiue YL, Yen CJ, Tang PC, et al. (2007). Laying traits and underlying transcripts, expressed in the hypothalamus and pituitary gland, that were associated with egg production variability in chickens. Theriogenology 68: 1305-1315.

Cui JX, Du HL, Liang Y, Deng XM, et al. (2006). Association of polymorphisms in the promoter region of chicken prolactin with egg production. Poult. Sci. 85: 26-31.

Dhillon SS, Gingerich S and Belsham DD (2009). Neuropeptide Y induces gonadotropin-releasing hormone gene expression directly and through conditioned medium from mHypoE-38 NPY neurons. Regul. Pept. 156: 96-103.

Dunn IC, Miao YW, Morris A, Romanov MN, et al. (2004). A study of association between genetic markers in candidate genes and reproductive traits in one generation of a commercial broiler breeder hen population. Heredity 92: 128-134.

El Halawani ME, Silsby JL, Rozenboim I and Pitts GR (1995). Increased egg production by active immunization against vasoactive intestinal peptide in the turkey (Meleagris gallopavo). Biol. Reprod. 52: 179-183.

El Halawani ME, Pitts GR, Sun S, Silsby JL, et al. (1996). Active immunization against vasoactive intestinal peptide prevents photo-induced prolactin secretion in turkeys. Gen. Comp. Endocrinol. 104: 76-83.

Emsley A (1997). Integration of classical and molecular approaches of genetic selection: egg production. Poult. Sci. 76: 1127-1130.

Hansen C, Yi N, Zhang YM, Xu S, et al. (2005). Identification of QTL for production traits in chickens. Anim. Biotechnol. 16: $67-79$.

Hirayama S, Bajari TM, Nimpf J and Schneider WJ (2003). Receptor-mediated chicken oocyte growth: differential expression of endophilin isoforms in developing follicles. Biol. Reprod. 68: 1850-1860.

Kim MH, Seo DS and Ko Y (2004). Relationship between egg productivity and insulin-like growth factor-I genotypes in Korean native Ogol chickens. Poult. Sci. 83: 1203-1208.

Klenke U, Constantin S and Wray S (2010). Neuropeptide Y directly inhibits neuronal activity in a subpopulation of gonadotropin-releasing hormone-1 neurons via Y1 receptors. Endocrinology 151: 2736-2746.

Kuo YM, Shiue YL, Chen CF, Tang PC, et al. (2005). Proteomic analysis of hypothalamic proteins of high and low egg 
production strains of chickens. Theriogenology 64: 1490-1502.

Leska A and Dusza L (2007). Seasonal changes in the hypothalamo-pituitary-gonadal axis in birds. Reprod. Biol. 7: 99126.

Lewis PD and Gous RM (2006). Effect of final photoperiod and twenty-week body weight on sexual maturity and early egg production in broiler breeders. Poult. Sci. 85: 377-383.

Liu HK, Lilburn MS, Koyyeri B, Anderson JW, et al. (2004). Preovulatory surge patterns of luteinizing hormone, progesterone, and estradiol-17beta in broiler breeder hens fed ad libitum or restricted fed. Poult. Sci. 83: 823-829.

Luo PT, Yang RQ and Yang N (2007). Estimation of genetic parameters for cumulative egg numbers in a broiler dam line by using a random regression model. Poult. Sci. 86: 30-36.

Proudman JA, Scanes CG, Johannsen SA, Berghman LR, et al. (2006). Comparison of the ability of the three endogenous GnRHs to stimulate release of follicle-stimulating hormone and luteinizing hormone in chickens. Domest. Anim. Endocrinol. 31: 141-153.

Reddy IJ, David CG and Raju SS (2007). Effect of suppression of plasma prolactin on luteinizing hormone concentration, intersequence pause days and egg production in domestic hen. Domest. Anim. Endocrinol. 33: 167-175.

Reutens AT and Begley CG (2002). Endophilin-1: a multifunctional protein. Int. J. Biochem. Cell Biol. 34: 1173-1177.

Rodríguez S, Gaunt TR, Dennison E, Chen XH, et al. (2006). Replication of IGF2-INS-TH*5 haplotype effect on obesity in older men and study of related phenotypes. Eur. J. Hum. Genet. 14: 109-116.

Sartsoongnoen N, Kosonsiriluk S, Prakobsaeng N, Songserm T, et al. (2008). The dopaminergic system in the brain of the native Thai chicken, Gallus domesticus: localization and differential expression across the reproductive cycle. Gen. Comp. Endocrinol. 159: 107-115.

Sasaki O, Odawara S, Takahashi H, Nirasawa K, et al. (2004). Genetic mapping of quantitative trait loci affecting body weight, egg character and egg production in F2 intercross chickens. Anim. Genet. 35: 188-194.

Schmidt A, Wolde M, Thiele C, Fest W, et al. (1999). Endophilin I mediates synaptic vesicle formation by transfer of arachidonate to lysophosphatidic acid. Nature 401: 133-141.

Schreiweis MA, Hester PY, Settar P and Moody DE (2006). Identification of quantitative trait loci associated with egg quality, egg production, and body weight in an F2 resource population of chickens. Anim. Genet. 37: 106-112.

Shacham S, Harris D, Ben-Shlomo H, Cohen I, et al. (2001). Mechanism of GnRH receptor signaling on gonadotropin release and gene expression in pituitary gonadotrophs. Vitam. Horm. 63: 63-90.

Sharp PJ (2005). Photoperiodic regulation of seasonal breeding in birds. Ann. Acad. Sci. 1040: 189-199.

Shiue YL, Chen LR, Chen CF, Chen YL, et al. (2006). Identification of transcripts related to high egg production in the chicken hypothalamus and pituitary gland. Theriogenology 66: 1274-1283.

Soñez MC, Soñez CA, Mugnaini MT, Haedo M, et al. (2010). Effects of differential pulse frequencies of chicken gonadotrophin-releasing hormone-I (cGnRH-I) on laying hen gonadotrope responses in vitro. Biotech. Histochem. 85: 355-363.

Tuiskula-Haavisto M, Honkatukia M, Vilkki J, de Koning DJ, et al. (2002). Mapping of quantitative trait loci affecting quality and production traits in egg layers. Poult. Sci. 81: 919-927.

Tuiskula-Haavisto M, de Koning DJ, Honkatukia M, Schulman NF, et al. (2004). Quantitative trait loci with parent-oforigin effects in chicken. Genet. Res. 84: 57-66.

Xu H, Shen X, Zhou M, Fang M, et al. (2010a). The genetic effects of the dopamine D1 receptor gene on chicken egg production and broodiness traits. BMC Genet. 11: 17.

Xu HP, Shen X, Zhou M, Luo CL, et al. (2010b). The dopamine D2 receptor gene polymorphisms associated with chicken broodiness. Poult. Sci. 89: 428-438.

Zhang K, Calabrese P, Nordborg M and Sun F (2002). Haplotype block structure and its applications to association studies: power and study designs. Am. J. Hum. Genet. 71: 1386-1394.

Zhou M, Lei M, Rao Y, Nie Q, et al. (2008a). Polymorphisms of vasoactive intestinal peptide receptor-1 gene and their genetic effects on broodiness in chickens. Poult. Sci. 87: 893-903.

Zhou M, Liang F, Rao Y and Zeng H (2008b). Association of twelve polymorphisms of the VIPR-1 gene with chicken early egg production traits. Chinese J. Anim. Vet. Sci. 39: 1147-1152.

Zhou M, Du Y, Nie Q, Liang Y, et al. (2010). Associations between polymorphisms in the chicken VIP gene, egg production and broody traits. Br. Poult. Sci. 51: 195-203. 